\title{
AN ANALYSIS OF AUDIT COMMITTEE EFFECTIVENESS AT THE LARGEST LISTED COMPANIES IN SOUTH AFRICA FROM A CFO AND AUDIT COMMITTEE PERSPECTIVE \\ Ben Marx: Department of Accountancy, University of Johannesburg
}

Purpose: The purpose of the study is to investigate and analyse the effective functioning of audit committees at the largest listed companies in South Africa.

Problem investigated: The modern audit committee is often seen as the panacea of the corporate world and as such is looked upon to cure all the financial reporting and control-related problems of entities. Audit committees are, however, not always as effective as they are held to be, as is evidenced by the many well-known corporate scandals and business failures that occurred where audit committees existed and fraudulent financial reporting, audit failures, internal control breakdowns and other irregularities prevailed. The modern audit committee will be of value only if it is properly constituted, is functioning effectively and if its role is clearly understood by all the parties concerned. The research problem investigated stems precisely from this issue, and the paper therefore aims to analyse the effective functioning of the audit committees at the largest listed companies in South Africa.

Methodology: The study empirically tested the audit committee practices at the largest listed companies in South Africa. This was done through questionnaires addressed to the CFOs and audit committee chairs.

Findings: The study found that audit committees at the largest listed companies in South Africa are well established, properly constituted, have the authority and resources to effectively discharge their responsibilities and consist of members who act independently and who have the right mix of appropriate experience, financial literacy and financial expertise amongst their members. The audit committee's role was found to be generally well understood and supported by the board and the Chief Financial Officers. It was further found that the audit committees are effective in discharging their oversight responsibilities on the board's behalf, with the only real exception being their effectiveness regarding IT-related aspects.

Value of research: The study provides valuable information on audit committee practices and the effectiveness of audit committees at the largest listed companies in South Africa. These findings can therefore serve as guidelines for best practice standards for audit committees at other companies and institutions.

Conclusion: Audit committees at the largest listed companies in South Africa were found to be well established and according to the views of the CFOs and audit committee chairs to be functioning effectively. Further research regarding the subject field of audit committees should focus on the status and effective functioning thereof at smaller companies, unlisted entities, higher education institutions and public sector entities.

Keywords: Audit committees, chief financial officer, corporate governance, audit committee effectiveness.

\section{INTRODUCTION}

Audit committees are not a new concept: the first audit committee was formed as early as 1872 by the Great Western Railway Company in the United Kingdom (Brewer, 2001:11). However, it is only in the last 10 to 15 years that audit committees have really come to the forefront. Many factors have given rise to renewed emphasis being placed on audit committees, the most significant of these being major corporate collapses and business failures, and the issuing of various corporate governance codes and new or amended legislation (Agulhas, 2006:30; Ernst \& Young, 2007:10-13; KPMG 2005:1-2; Marx, 2008:5-13; 175-205 Payne, 2002; Terry, 2007:33).

The modern audit committee can be defined as a subcommittee of the board of directors that consists of a majority of independent non-executive directors tasked with an oversight role to assist the directors in meeting their financial reporting, risk management and control- and audit-related responsibilities (Marx, 
2008:1) Accordingly, the audit committee forms an integral part of the governance structures of a board of directors of a company (or other entities) and can be seen to act as the financial guard dog of the shareholders specifically, and all the stakeholders at large, in ensuring accurate and reliable financial reporting and dealing with emerging issues, such as fostering an ethical culture in doing business (Blue Ribbon Commission, 1999:6-7; Marx, 2008:326-334; PricewaterhouseCoopers, 2006:1;Van der Nest, 2006;v; Wixley \& Everingham, 2005:51). The credit crunch and the challenging economic environment will also bring an increased risk of unethical behaviour and the potential for fraud, and have resulted in company boards increasingly looking to their audit committees to provide them with assurance that these risks are adequately addressed (Ernst \& Young, 2009:3).

The modern audit committee is, however, facing new and extended challenges which PricewaterhouseCoopers (2005:4) describes as follows: "corporate financial reporting continues to be under intense scrutiny by regulators, securities analysts, institutional investors and others - placing audit committees firmly in the spotlight. Numerous and increasing responsibilities are driving audit committees' workload, along with the need to establish strong working relationships with management and auditors. Audit committees are also trying to find an appropriate balance between overseeing and advising management, while avoiding micromanaging". This opinion is supported by, inter alia, Deloitte (2006:1): "emerging practices and public expectations continue to affect the roles, responsibilities and behaviour of audit committees".

It is also essential that audit committees should be effective in their functioning and not merely be formed as window-dressing or to meet legislative or regulatory requirements. The above view is supported by Carroll and Buchholtz in their book entitled Business and Society: Ethics and Stakeholder Management, in which they express support for audit committees by stating that "recent scandals, like Enron and WorldCom, and the many corporations that have subsequently needed to restate earnings underscore the importance of a strong audit committee". They also warn of the danger, however, that audit committees might exist only in appearance and not be effective in their governance oversight role. They refer to an article in the Wall Street Journal that stated that "too many audit committees are turning out to be toothless tigers" (Carroll \& Buchholtz, 2006:619).

The remainder of this paper is organised as follows. The next section presents the theoretical background and the objective of the paper. The sections that follow then describe the methodology applied and present the research results and an analysis and interpretation of the findings. Generalisations and recommendations drawn from the study are then provided, and conclusions are presented in the final section.

\section{THEORETICAL BACKGROUND}

Financial reporting has become very technical and complex (Ernst \& Young, 2006:6; Green \& Gregory, 2005:56; Marx, 2008:77-78) and the independence of external and internal auditors is under constant threat (Bailey, 2007:47; Marx, 2008:290, 296, 309). Add to this the pressure on management to produce good results in an ever-competitive and now global economy (Marx, 2008:73-75) and it is clear that the need exists for a small, highly skilled and independent committee to assist the board of directors in meeting its financial reporting, auditing, control and risk management and other related responsibilities. Therefore it is evident that an effectively functioning audit committee can greatly assist the board of directors in this regard.

An effective audit committee will also be beneficial for the shareholders and stakeholders alike. Park (1998:iv) found that the results of two empirical studies (part of a doctoral thesis in the USA) suggest that companies with effective audit committees are less likely to have financial and auditing problems and consequently that the capital markets respond more favourably to earnings news from such companies. This is supported by KPMG (2005:82), which emphasized the importance of audit committees being properly constituted and described the resultant benefit as follows: "a corporate board of directors establishes an audit committee to assist in discharging its fiduciary responsibility. How the committee fulfils that mandate varies according to the clarity of the committee's mission, the abilities of the 
committee's members, and the tone set at the top of the governance structure. An audit committee that operates effectively is a key feature in a strong corporate governance culture, and can bring significant benefits to the company."

An audit committee can only be effective if it has the right characteristics. Thus the value of an effective audit committee hinges on the characteristics it possesses. This was described as follows as far back as 1994 by English, who conducted research on audit committees in Australia in the early 1990s: "the value of an audit committee is directly related to the calibre of its members, its status in the eyes of the board and senior management and its charter" (English, 1994). Audit committees can also only be effective if the audit committee members themselves, as well as all the parties the committee interacts with, clearly understand and respect the committee's rights, duties and responsibilities. Only then will there be honest, open and constructive dialogue and interaction between the relevant parties and the audit committee.

An overview of relevant literature (Brewer, 2001; Ernst \& Young, 2005; Ferreira, 2008; Institute of Directors (hereafter loD); 2006; Marx \& Lubbe, 1993; Marx, 2008; Payne, 2002; PricewaterhouseCoopers, 2005; PricewaterhouseCoopers, 2006; Rager, 2004; Spira, 2003; Stewart \& Munro, 2007; Wayne, 2003; Weiss, 2005) revealed the following to be essential aspects for audit committees to be effective (these aspects formed the basis of the research questions of the empirical study as discussed in Table 2):

- That the board should understand and respect the role, position, limitations and responsibilities of the audit committee and the value it can bring to the board. This might not always be the case, however, as some boards and board chairmen can at the one extreme see the audit committee as a burden, a necessary nuisance imposed on them by legislation, codes of corporate governance, etc. or an additional cost. At the other extreme the board can see the audit committee as the be-all and end-all of its financial reporting and related responsibilities, and assign tasks to the committee that are outside its remit;

- That the audit committee and all its members should understand its role, responsibilities, limitations and importance. The audit committee will only be effective if it is properly constituted, consists of qualified and experienced members, understands its responsibilities and performs them with vigour and dedication;

- That all the parties that interact with the audit committee, but specifically financial management and the external and internal auditors, should understand the status, role and responsibilities of the audit committee. For the audit committee to effectively perform its financial reporting and control oversight role, it is essential that the committee is provided with all the relevant information and facts in an open, honest and transparent manner. As such, the internal and external auditors are often seen as the 'eyes and ears' of the audit committee. For this to be effective, it is imperative that the independence of the internal and external auditors is embedded in the audit committee charter, and supported, in fact and appearance, through its structures and operations. Similarly, management should at all times understand the role and function of the audit committee, and be encouraged and feel free to discuss financial reporting, and control- and audit-related issues in an open, honest and frank manner with the audit committee.

The responsibilities of the audit committee traditionally centred on assisting the directors in meeting their financial reporting, control- and audit-related responsibilities. The role of the modern audit committee has evolved since the early 1990s, however, and, given the development and constant change in the business environment in which entities operate, additional responsibilities have been given to the audit committee. This is illustrated by the following responsibilities that the audit committee is tasked with by, inter alia, the Combined Code of 2006 (Financial Reporting Council, 2006:para. C3.2) in the United Kingdom:

- To monitor the integrity of the financial statements of the company and any formal announcements relating to the company's financial performance, reviewing significant reporting judgements contained in them; 
- To review the company's internal financial controls and unless expressly addressed by a separate board risk committee composed of independent directors, or by the board itself, to review the company's internal control and risk management;

- To monitor and review the effectiveness of the company's internal audit function;

- To make recommendations to the board, for it to put to the shareholders for their approval in a general meeting, in relation to the appointment, re-appointment and removal of the external auditor and to approve the remuneration and terms of engagement of the external auditor;

- To review and monitor the external auditor's independence and objectivity and the effectiveness of the audit process, taking into consideration relevant United Kingdom professional and regulatory requirements;

- To develop and implement a policy on the engagement of the external auditor to supply non-audit services, taking into account relevant ethical guidance regarding the provision of non-audit services by the external audit firm; and

- To report to the board, identifying any matters in respect of which it considers that action or improvement is needed and making recommendations as to the steps to be taken.

The second King Report in South Africa contains similar responsibilities (Institute of Directors, 2002:section 5, para. 5.7), but in addition tasks the audit committee with reviewing the company's compliance with legal and regulatory provisions, its articles of association, code of conduct, bylaws and the rules established by the board. One of the new responsibilities also assigned to the audit committee in the King Report is that of oversight responsibility for risk management. Audit committees are also increasingly given the responsibility for monitoring ethics compliance and whistle-blowing hotlines and IT governance (Haden, 2002:1; Institute of Internal Auditors (hereafter IIA), 2006:4; PricewaterhouseCoopers, 2005:23). The third King Report (draft) proposes further responsibilities for audit committees, such as taking oversight responsibility for sustainability reporting and satisfying itself of the expertise, resources and experience of the finance function (IoD, 2009; para. 3.4.4 and para. 3.5).

The modern audit committee may however also experience significant challenges, threats and limitations, which might negatively impact on its effectiveness. These include unrealistic expectations of audit committees, the availability of suitable candidates to serve on audit committees and greater risk exposure, to name but a few (Aghulhas, 2006:30-31; Casarino and Van Esch, 2005:179)

From the above discussions it then follows that the following are critical aspects for audit committee effectiveness. The extent to which these are currently being applied in South Africa will be tested in the empirical work as follows:

- Establishment and status of audit committees, e.g. whether audit committees are established under a formal charter, which is regularly reviewed and approved by the board, and whether audit committees are supported by their boards and provided with the resources and authority to effectively discharge their responsibilities;

- Membership characteristics, e.g. whether audit committees consist of independent non-executive directors with the necessary experience, financial literacy and financial expertise;

- Relationship with the board, e.g. whether boards understand the role of their audit committees and the responsibilities performed by them on the boards' behalf;

- Specific responsibilities performed by audit committees, covering both the traditional responsibilities of financial reporting, control and auditing, as well as evolving responsibilities such as business ethics, corporate governance and IT-related aspects. 


\section{OBJECTIVE OF THE EMPIRICAL STUDY}

Although audit committees are already well established in South Africa as well as overseas, they are not always as effective as they could be in their governance oversight role. Limited empirical research has also been done to date (Marx 2008:540-568) on the status and functioning, and accordingly the effectiveness, of audit committees in South Africa. Given the important role that an audit committee can play in the governance structure of the board regarding financial reporting, control and risk management and other related aspects, and the recent developments in the legal, regulatory and business environment in South Africa, the need exists for empirical data to assess current audit committee practices and audit committee effectiveness and to provide a foundation for future recommendations.

Accordingly the objective of the study was to analyse current audit committee practices and audit committee effectiveness at the largest listed companies in South Africa.

\section{METHODOLOGY}

The study consisted of questionnaires that were sent to the CFOs and audit committee chairs of the companies in the population. The role of the CFO is evolving and constantly increasing in scope and importance (Ernst \& Young, 2008: 1-3; KPMG, 2008:1-17; Voogt, 2008:1) and accordingly the CFO as custodian and provider of financial information to the audit committee is of immense importance. Accordingly the CFOs were selected as respondents to the first questionnaire with the aim of obtaining their views on the effectiveness of their audit committees from a management perspective. The audit committee chairs were selected as respondents to the second questionnaire as they were considered to be best placed to provide information on the effectiveness of their audit committees.

The study focused on audit committees at the largest listed companies in South Africa and accordingly the population for the empirical study was selected as the largest 40 companies ranked by market capitalisation on the JSE's All-Share Index (referred to as the FTSE/JSE Top 40 Index) (JSE 2007b:1213). On 28 November 2007 the companies of the FTSE/JSE Top 40 Index represented $86.39 \%$ of the total market value of the JSE's All-Share Index (JSE, 2007a) and on 27 February 2008 these companies represented $87.64 \%$ (JSE, 2008a; JSE, 2008b). From these statistics it is evident that the companies included in the population represent the largest companies in market value (almost $90 \%$ in total) on the JSE and as such would represent a wide spectrum of stakeholders' interests, and shareholders' wealth, in South Africa.

\section{Response rate}

In audit committee literature the general response rates for both empirical studies and professional surveys are relatively low. In this regard Brewer (2001:74) reported response rates of between $21 \%$ and of $61 \%$ for empirical research on audit committees conducted in the USA between 1970 and 1998. More recently, Hadden (2002:61) reported a response rate of 5.47\% and Weiss (2005:40) a response rate of $10 \%$ for empirical studies involving audit committees in the USA. As stated in the previous section, limited research has so far been done on audit committees in South Africa. The most recent empirical study of audit committees at companies in South Africa is that of Brewer (2001:73), who reported a response rate of $37.6 \%$ in 2000 . The response rate for professional surveys are not much better as, inter alia, PricewaterhouseCoopers $(2005: 133)$ reported a response rate of $17 \%$ for their surveys of audit committee chairs in the USA in 2005 and Ernst \& Young (2005:10) reported a response rate of 25\% for their survey of audit committees at listed companies in South Africa in 2005. 
The response rate for both categories of respondents in the study was as follows:

Table1: Response rate

\begin{tabular}{|l|c|c|c|c|}
\hline \multirow{2}{*}{} & \multicolumn{2}{|c|}{$\begin{array}{c}\text { Questionnaire } \\
\text { to the } \\
\text { CFOs }\end{array}$} & \multicolumn{2}{c|}{$\begin{array}{c}\text { Questionnaire } \\
\text { to the } \\
\text { Audit committee } \\
\text { chairs }\end{array}$} \\
\cline { 2 - 5 } & $\begin{array}{c}\text { Numbe } \\
\mathbf{r}\end{array}$ & $\%$ & Number & $\%$ \\
\hline No response & 4 & 10.0 & 4 & 10.0 \\
\hline $\begin{array}{l}\text { Correspondence received - policy is not to complete } \\
\text { questionnaires or surveys }\end{array}$ & 2 & 5.0 & 2 & 5.0 \\
\hline Completed and usable questionnaires & 34 & 85.0 & 34 & 85.0 \\
\hline Total and percentage of questionnaires sent out & $\mathbf{4 0}$ & $\mathbf{1 0 0}$ & $\mathbf{4 0}$ & $\mathbf{1 0 0}$ \\
\hline
\end{tabular}

The response rate achieved for this study of $85 \%$ useable questionnaires received back from both the CFOs and audit committee chairs is deemed to be very high and should contribute to the reliability and usefulness of the information therein. The high response rate could also be seen as support for the importance of audit committees at the large listed companies in South Africa and further contributes to the existing body of knowledge on audit committee practices in South Africa.

\section{RESEARCH FINDINGS AND INTERPRETATION}

This section presents the responses received from the questionnaires and provides a comparison of the views of the audit committee chairs and the CFOs regarding the effectiveness of their audit committees.

Table 2: Comparison of the views of the CFOs and audit committee chairs on the effectiveness of their audit committees

\begin{tabular}{|l|c|c|}
\hline & $\begin{array}{c}\text { CFO } \\
\text { question- } \\
\text { naire } \\
\text { (\%) }\end{array}$ & $\begin{array}{c}\text { AC chair } \\
\text { question- } \\
\text { naire } \\
\text { (\%) }\end{array}$ \\
\hline $\begin{array}{l}\text { Are you of the opinion that your board of directors } \\
\text { understands: }\end{array}$ & 100 & 100 \\
$\begin{array}{l}\text { The role of the audit committee? } \\
\text { The value it can add to the board? }\end{array}$ & 100 & 100 \\
\hline $\begin{array}{l}\text { Are you of the opinion that your board of directors } \\
\text { fully supports: }\end{array}$ & 100 & 100 \\
$\begin{array}{l}\text { The audit committee? } \\
\text { The role that the audit committee plays? }\end{array}$ & 100 & 100 \\
\hline $\begin{array}{l}\text { Are you of the opinion that all the members of your } \\
\text { audit committee understand: }\end{array}$ & 100 & 100 \\
$\begin{array}{l}\text { The objective of the audit committee? } \\
\text { The functions and responsibilities of the audit } \\
\text { committee? }\end{array}$ & 100 & 100 \\
\hline $\begin{array}{l}\text { Are you of the opinion that your audit committee: } \\
\text { Is properly constituted? }\end{array}$ & 97.1 & 91.2 \\
$\begin{array}{l}\text { Operates according to a well-formulated charter? } \\
\text { Is provided with the necessary authority to be able to } \\
\text { effectively discharge its responsibilities? }\end{array}$ & 100 & 100 \\
$\begin{array}{l}\text { Is provided with the necessary resources to be able to } \\
\text { effectively discharge its responsibilities? }\end{array}$ & 97.1 & 100 \\
\hline \begin{tabular}{l} 
Are you of the opinion that your audit committee \\
\hline
\end{tabular} & & \\
\hline
\end{tabular}


consist of members:

Who act independently?

Who have the right mix of appropriate experience?

Of sufficient number who are financial literate (i.e. able

to read and understanding financial statement)?

Of sufficient financial expertise (i.e. formal qualifications

in accounting and/or auditing)?

Are you of the opinion that your audit committee is effective in discharging its responsibilities regarding:

The external audit function?

The external auditor's independence?

The internal audit function?

The internal auditor's independence?

Financial reporting?

Internal controls?

Risk management?

Business ethics?

Corporate governance?

Legal and regulatory aspects?

IT-related aspects?

IT governance?

Are you of the opinion that audit committees should be regulated:

By the JSE (currently a listing requirement)?

Statutorily by legislation (as required in section 260 of

the Companies Amendment Act, 2007)?

By corporate governance codes only?

Source: CFO questionnaire and audit committee questionnaire

\begin{tabular}{|l|l|}
\hline & \\
97.1 & 100 \\
94.1 & 97.1 \\
94.1 & 97.1 \\
& \\
88.2 & 91.2 \\
& \\
& \\
& \\
100 & 97.1 \\
100 & 97.1 \\
85.3 & 91.2 \\
91.2 & 85.3 \\
91.2 & 97.1 \\
85.3 & 94.1 \\
85.3 & 79.4 \\
94.1 & 82.4 \\
82.4 & 91.2 \\
85.3 & 88.2 \\
44.1 & 35.3 \\
35.3 & 32.4 \\
\hline & \\
47.1 & 57.6 \\
58.8 & 57.6 \\
& \\
50.0 & 51.5 \\
\hline
\end{tabular}

\section{Key interpretations based on the above findings:}

The CFOs and audit committee chairs alike are of the opinion that their boards understand the role and value of their audit committees and fully support them. They are also of the opinion that their audit committee members understand the objective, functions and responsibilities of their audit committees.

Both groups are also confident that their audit committees are properly constituted, operate under a wellformulated charter and have the authority and resources to effectively discharge their responsibilities. As far as the membership is concerned, they are of the opinion that their audit committee members act independently and have the right mix of appropriate experience and financial literacy. Most of them are also of the opinion that sufficient financial expertise exists amongst the members of their audit committees.

The CFOs and the audit committee chairs alike are of the opinion that their audit committees are effective in performing their core oversight responsibilities of financial reporting and auditing, control and risk management and related responsibilities, while they are less confident that their audit committees are effective in discharging their oversight responsibilities regarding IT-related aspects.

The strongest support for formal regulation of audit committees comes from the audit committee chairs, who are slightly more in favour of formal regulation of audit committees by the JSE and statutorily by the Companies Act, rather than voluntary compliance through corporate governance codes only. However, some views have been expressed that over-regulation should be avoided. 


\section{GENERALISATIONS AND RECOMMENDATIONS}

From the above information it is evident that audit committees at the largest listed companies in South Africa are effectively constituted, understood and supported by their boards and considered to be effective in their functioning. There are however aspects that need attention to ensure that audit committees remain effective in the future. These include aspects relating to members' financial literacy and financial expertise, IT-related responsibilities, risk management and business ethics.

Following from the results of the study it is recommended that all companies consider forming audit committees in order to utilise the benefits they offer. This should apply irrespective of legislation or regulations in this regard. Furthermore, it is recommended that audit committees should be optimally utilised in both the private and public sector to ensure accurate, credible and reliable financial reporting and to facilitate and support effective internal controls and risk management systems.

It is further recommended that audit committees should not merely exist in name, but should be effective in functioning. Accordingly, they must be supported by the board and have all the necessary resources, support and authority to effectively discharge their responsibilities. The committee should consist of members who are independent, financially literate and have the necessary financial expertise and should diligently perform the responsibilities entrusted to them by the audit committee charter, but must be careful not to accept responsibilities that they are not qualified for, have the time to perform, or that fall outside their remit.

\section{CONCLUSION}

In conclusion, the paper found strong supportive evidence, according to the views of the CFOs and audit committee chairs, that the audit committees at the largest listed companies in South Africa currently are well established, accepted and supported by both their boards and their CFOs. The audit committees were also found to be well constituted of members who act independently and have the necessary experience and financial expertise. The audit committees were also found to be discharging the responsibilities normally entrusted to them by corporate governance codes and best practice standards, which included risk management and legal and regulatory compliance, and to a lesser extent business ethics, with the real exception being their effectiveness in discharging their IT-related responsibilities. From these findings it can be concluded that these audit committees are not merely established for window dressing purposes, or to comply with legal or regulatory requirements, but are effective in their financial oversight and control-related responsibilities. This state of affairs should contribute to financial reporting that is accurate, transparent and reliable in future.

The findings of the study, however, must be treated with caution because the study was restricted to the largest listed companies in South Africa. Therefore, the results reported in this paper should not be generalised to smaller listed companies, unlisted entities or public sector institutions. Accordingly it is recommended that areas for future research should focus on the effective functioning of audit committees at smaller companies, as well as those listed on the AltX (the listing for small to medium companies that are in a growth phase). These companies might have unique circumstances that require different audit committee requirements.

The effective functioning of audit committees in the public sector should also be investigated. The public sector forms an important part of the economy and is critical for the effective delivery of public services. In this regard effective audit committees should significantly contribute to increasing the level and reliability of financial reporting and the effectiveness of internal controls and risk management systems.

A further area of research into audit committees is the role and effective functioning of audit committees at Higher Education Institutions in South Africa. Higher education is critical to the success of the country and the role of effective audit committees at these institutions to ensure accurate, reliable and credible financial reporting and effective systems of risk management is essential. 
Lastly, it is recommended that a comparative analysis of the findings of this study with those aspects that are included in the third King Report and the new Companies Act, when enacted and effective, should be conducted.

\section{REFERENCES}

Algulhas, B. (October 2006). Can audit committees make a (real) difference? Without Prejudice: 30-31.

Bailey, J.A. (April 2007). A Symbiotic Relationship. Internal Auditor: 45-48.

Blue Ribbon Committee, (1999). Report and Recommendations of the Blue Ribbon Committee on Improving the Effectiveness of Corporate Audit Committees. New York Stock Exchange and the National Association of Securities Dealers. New York. USA.

Brewer, F.C. (2001). Corporate audit committee effectiveness. Unpublished research report submitted in partial fulfilment of the requirements for the degree Masters of Commerce. Johannesburg: University of the Witwatersrand. December.

Carroll, A.C. \& Buchholtz, A.K. (2006). Business \& Society: Ethics and Stakeholder Management. Ohio: Thomson South-Western.

Casarino, R. \& Van Esch, S. (2005). Internal Auditing - An Integrated Approach. Landsdown. South Africa: Juta \& Co.

Deloitte. (2006). Audit Committee Resource Guide. Deloitte Development LLC. Member of Deloitte Touche Tohmatso. USA.

English, L. (April 1994). Making audit committees work. Australian Accountant, 64(3). Available from: http://0-

proquest.umi.com.raulib.rau.ac.za:80/pqdweb?index $=3 \ldots$ ROD \&VType=PQD\&RQT $=309 \& V$ Name $=P Q D \& T$ $\underline{S=1143572142 \& \text { clientld }=57200}$ (Accessed 3 January 2006).

Ernst \& Young. (2005). Audit committee benchmarking survey. South Africa.

Ernst \& Young. (2006). Transition to IFRS - The final analysis results. South Africa.

Ernst \& Young. (2007). Four lessons for audit committees from high-profile accounting scandals. Viewpoints from the Audit Committee Leadership Summit. Tapestry Networks, Inc. Available from: http://www.tapestrynetworks.com

Ernst \& Young. (2008). What's next for the CFO?. Global Survey. EYGM Limited.

Ernst \& Young. (2009). Managing risk in the current climate. BoardMatters Quarterly: Critical Insights for Today's Audit Committee. EYGM Limited.

Ferreira, I. (2008). The effect of audit committees composition and structure on the performance of audit committees. Meditari, 16(2): 89-106.

Financial Reporting Council. (2006). The Combined Code of Corporate Governance. Available from: http://www.ecgi.org/codes/code.php?code id=198 (Accessed 20 September 2007).

Green, S. \& Gregory, H.J. (February 2005). The Ripple Effect. Internal Auditor: 48-56.

Hadden, L.B. (2002). An investigation of the audit committee and its role in monitoring information technology risks. Dissertation submitted to $\mathrm{H}$. Wayne Huizenga School of Business and 
Entrepreneurship. Nova Southeastern University in partial fulfilment of the requirements for the degree of Doctor of Business Administration. UMI Dissertation Services.

Institute of Directors. (2002). King II Report on Corporate Governance, Institute of Directors in Southern Africa. Johannesburg.

Institute of Directors. (loD). (2006). Audit Committee Forum. (Sponsored by KPMG). Corporate governance survey results. South Africa.

Institute of Directors. (IoD). 2009. King Report on Corporate Governance. Institute of Directors in Southern Africa, Johannesburg, South Africa.

Institute of Internal Auditors. (IIA). (2006). The Audit Committee: Prepare, Process, Professionalism. Almonte Springs, Florida. USA.

JSE Limited. (JSE). (2007a). JohnB@jse.co.za 30 November 2007. Percentages. Email to marxb@mweb.co.za

JSE Limited. (JSE). (2007b). Ground Rules for the Management of the FTSE/JSE Africa Index Series. Indices Department. JSE Limited. Sandton, Johannesburg. Available from:

http://ftse.jse.co.za/does/general information/FTSE JSE Ground Rules.pdf. (Accessed 27 February 2008).

JSE Limited. (JSE). (2008a). NongceboM@jse.co.za. 3 March 2008. Indices: Information request for study purposes. Email to marxb@mweb.co.za.

JSE Limited. (JSE). (2008b). Janniel@jse.co.za. 13 May 2008. CHAPTER SEVEN-28-02-jbNAVRAAG.doc. Email to marxb@mweb.co.za.

KPMG. (2005). Toolkit for the audit committee. $1^{\text {st }}$ edition. Johannesburg. South Africa. ISBN 1-87508242-5.

KPMG. (2008). Being the Best: The evolution of local finance functions. Johannesburg. South Africa.

Marx, B. \& Lubbe, D.S. (1993). Enkele empiriese bevindinge aangaande die funksionering van ouditkomitees by groot maatskappye in Suid-Afrika. Meditari, 1(1): 43-60.

Marx, B. (2008). An analysis of the development, status and functioning of audit committees at large listed companies in South Africa. Unpublished thesis submitted in fulfilment of the requirements for the degree Doctor Commercii in the Faculty of Economic and Financial Sciences. Johannesburg: University of Johannesburg.

Park, Y.K. (1998). Audit committees, corporate governance and the quality of financial reporting: Evidence from auditor litigation and market reactions to earnings announcements. Submitted to the Graduate Faculty of Joseph M Katz Graduate School of Business in partial fulfilment of the requirements for the degree of Doctor of Philosophy. University of Pittsburgh. UMI Dissertation Services.

Payne, N. (March 2002). The Enron meltdown. Accountancy SA (asa). Available from: http://www.accountancysa.org.za/archives/2002mar/columns/enron.htm (Accessed 28 May 2002).

PricewaterhouseCoopers. (2005). Audit Committee Effectiveness - What works best. $3^{\text {rd }}$ edition. Report by PricewaterhouseCoopers (sponsored by the Institute of Internal Auditors Research Foundation). USA. 
PricewaterhouseCoopers. (2006). Results of audit committee benchmarking survey of good practices for listed companies. PricewaterhouseCoopers LLP. United Kingdom.

Rager, L.A. 2004. The effectiveness of independent audit committee directors with accounting certifications in preventing reporting irregularities in publicly traded companies. Dissertation submitted to $\mathrm{H}$. Wayne Huizenga School of Business and Entrepreneurship. Nova Southeastern University in partial fulfilment of the requirements for the degree Doctor of Business Administration, Accounting Specialisation. UMI Dissertation Services.

Spira, F. (2003). Audit Committees: begging the question. Corporate Governance: An International Review, 11(3): 180-188. Available from: http://www.blackwell-synergy.com/doi/abs/10.1111/14678683.00317? prevSearch=\%28\%28\%28author\%3A\%28Spira\%29\%29+AND+title\%3A\%28Audit+committe es\%5C\%3A+begging+the+question\%29\%29\%29 (Accessed 11 August 2007).

Stewart, J. \& Munro, L. (2007). The Impact of Audit Committee Existence and Audit Committee Meeting Frequency on the External Audit: Perceptions of Australian Auditors. International Journal of Auditing, 11(1): 51-69. Available from:

http://www.blackwell-

synergy.com/action/showFullText?submitFullText=Full+Text+HTML\&doi=10.1111\%2Fi.1099-

1123.2007.00356.x (Accessed 8 November 2007).

Terry, G. (April 2007). Enron. Lessons learned. Accountancy SA (asa): 32-44.

Van der Nest, D.P. (2006). Audit committees in the South African Public Service. Unpublished thesis submitted on partial fulfilment of the requirements for the degree Doctor Technologiae in the Faculty of Economic Sciences. Pretoria: Tshwane University of Technology.

Voogt, T.L. (2008). Phase 1 of The SAICA CFO of the Future Project: A Process Report. Conference proceedings: Value 2008: Creating, Developing and Delivering Value in Africa in the Global Context held at Sun City, South Africa, 26-28 May 2008. JEL Code: M10. The Faculty of Economic and Financial Sciences: University of Johannesburg.

Wayne, P.F. (2003). An investigation of the determinants of audit committee effectiveness. Doctoral dissertation submitted to the Faculty of Graduate Studies. Schulich School of Business. Toronto, Canada. York University. UMI Dissertation Services.

Weiss, R. (2005). Audit committee characteristics and monitoring effectiveness. Dissertation submitted to the Graduate Faculty of Business in partial fulfilment of the requirements for the degree of Doctor of Philosophy. New York: City University of New York. UMI Dissertation Services.

Wixley, T. \& Everingham, G. (2005). Corporate governance. Cape Town: Siber Ink. 